\title{
EFFECTS OF DIFFERENT TYPES OF CONCRETE TOPPINGS ON THE BEHAVIOR OF PPHC SLABS
}

\author{
A. Nabil ${ }^{1}$, N. Meleka ${ }^{2}$, and Kh. Heiza ${ }^{3}$ \\ 1. PhD Candidate at Department of Civil Engineering, Faculty of Engineering, \\ Menoufia University, Egypt \\ 2. Professor of Reinforced Concrete Structures at Department of Civil Engineering, \\ Faculty of Engineering, Menoufia University, Egypt \\ 3. Professor of Reinforced Concrete Structures and Vice Dean for Community Services \\ and Environmental Development at Faculty of Engineering, Menoufia University, \\ Egypt
}

\begin{abstract}
Usage of precast prestressed concrete hollow core (PPHC) slabs has been extensively spread out in roofing and flooring systems around the globe due to benefits of mass production and fast site construction. In this flooring system, prestressed precast hollow core slabs are used together with or without a cast in place concrete topping. A few research works focused on studying the effect of using concrete topping on enhancement of the structural integrity of the PPHC system. This paper presents an experimental study conducted to investigate the effects of using different types of cast in place (CIP) concrete toppings on the behavior of PPHC slabs. Ten typical full scale specimens of PPHC slabs were prepared in precast concrete plant under quality control program; specimens were classified into five groups. Group (1) includes two control specimens without topping, Group (2) contains two specimens with ordinary reinforced concrete topping, Group (3) involves two specimens with ordinary reinforced concrete topping connected to the top surface of the slab using steel anchors, Group (4) comprises two specimens with fibrous concrete topping, and finally Group (5) includes two specimens with ferrocement topping. All test specimens were tested under static line loading until failure. Cracking patterns, failure modes, cracking and ultimate failure moment capacities, and moment- deflection relationship have been illustrated, discussed, and analyzed in this study. Adding concrete topping to the PPHC slabs enhances flexural behavior directly under static line loading, as the cracking moment resistance was increased by about $6 \%$ to $31 \%$ and failure moment was increased by about $11 \%$ to $41 \%$ by using concrete toppings.
\end{abstract}

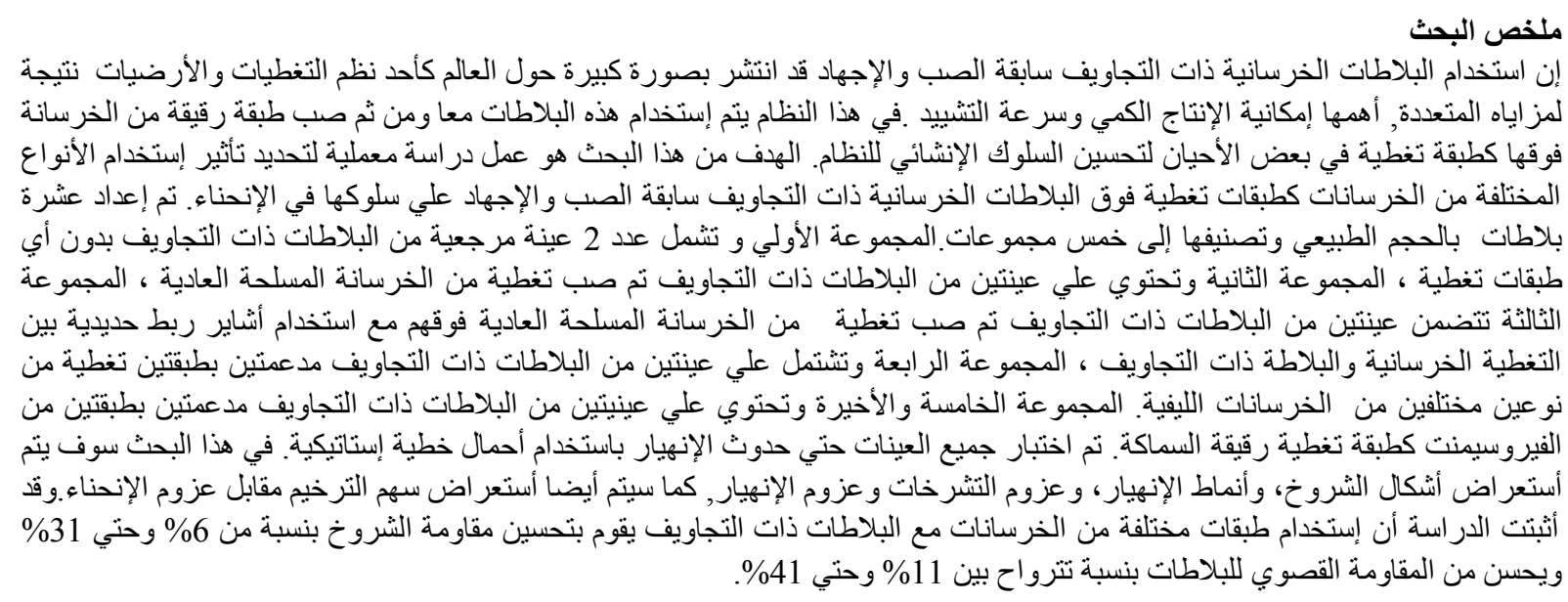

Keywords: Hollow core slabs; Precast concrete; Prestressed concrete; Fibrous concrete; Ferrocement; Concrete toppings; Steel anchors.

\section{INTRODUCTION}

Prestressed concrete hollow-core slabs have been widely used throughout the world in concrete and steel structures ${ }^{[1,2]}$. They were developed in the 1950 s when long-line prestressing techniques evolved with the extrusion method, which allow production of inexpensive and easy-to-handle PPHC slabs ${ }^{[3]}$. PPHC slabs can be defined as precast, prestressed concrete members with continuous voids provided to reduce weight and, therefore, cost and, as a side benefit, to use for concealed electrical or mechanical runs ${ }^{[4,5]}$. They are primarily used in floors and roofs of 
residential, commercial, industrial and institutional

\begin{tabular}{|c|c|c|c|}
\hline Group & Slab & Concrete & Steel \\
\hline Group & $\mathrm{C} 1$ & No topping & No \\
\hline Group & TRC1 & Ordinary RC & No \\
\hline \multirow{2}{*}{$\begin{array}{c}\text { Group } \\
3\end{array}$} & TRCA1 & Ordinary RC & Anchors at \\
\hline & TRCA2 & Ordinary RC & Anchors at \\
\hline \multirow{2}{*}{$\begin{array}{c}\text { Group } \\
4\end{array}$} & TSFC1 & Steel fiber & No \\
\hline & TGFC2 & Glass fiber & No \\
\hline Group & TFERO1 & Ferrocement & No \\
\hline
\end{tabular}

buildings $^{[6]}$. PPHC slabs have good fire resistance, sound insulation properties, and are capable of spanning long spances with relatively shallow depths. Common depths of prestressed hollow-core slabs range from 150 to $500 \mathrm{~mm}$ which can achieve $20 \mathrm{~m}$ of span on roofs ${ }^{[7]}$.

There are a number of situations where it may become necessary to increase the structural performance of concrete members either to incorporate and satisfy the codes modifications or to allow for any change of use and the associated changes in superimposed loads ${ }^{[8,9]}$. In recent years, the cement-base bonded overlay technique has been used to strengthen and enhance the structural performance of precast concrete slabs by adding a thin layer of cast in-situ reinforced concrete to the existing $\mathrm{slab}^{[10]}$. The primary purpose of this technique in PPHC slabs is to overcome the camber caused by prestressing, which results in an uneven floor surface. Besides creation of a semi-rigid diaphragm that connects hollow core slabs units together. This concrete layer consequently improves the load-carrying capacity and stiffness of the slab by increasing its thickness ${ }^{[11,12,13,14]}$. The main purpose of the current study is identifying the extent to which different types of CIP concrete topping placed over surface of precast concrete hollow-core units improves the flexural behavior of the slabs.

\section{EXPERIMENTAL PROGRAM}

\subsection{Test specimens}

The aim of experimental work carried out in this study is to investigate the effect of using different types of structural concrete topping (screed) with and without using connecting steel anchors on structural behavior of PPHC slabs subjected to static line loads. For this purpose, ten full scale PPHC slabs were prepared. All specimens have a length of $4,100 \mathrm{~mm}$, a depth of 160 $\mathrm{mm}$ and a width of 1,200 mm. Experimental program was done in two stages: first stage in which specimens were prepared, was carried out at Modern Concrete factory and lab facility at Sadat city (local precast manufacturer), while loading and tests were at the second stage, which was developed at the Prof.
Mounir Hussein's Reinforced Concrete laboratory of the Civil Engineering Department of Menoufiya University. The test specimens classifications and naming convention are listed as shown in Table 1.

Table 1: Experimental test program

Geometry, cross section, and details of test groups are illustrated in Figs. 1 - 5.

\subsection{MATERIAL PROPERTIES}

\subsection{1 . Concrete materials}

\section{a. Ordinary concrete}

Test specimens of-PPHC slabs were manufactured in Modern Concrete precast plant. The average 28-day cube compressive strength of these slabs is $50 \mathrm{MPa}$. The

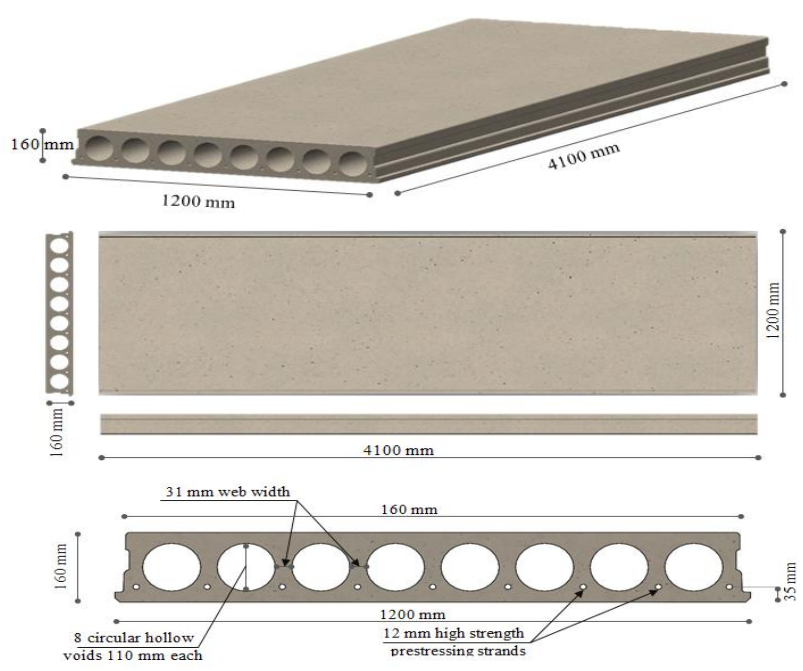

Fig. 1: Details for control specimen of Group 1

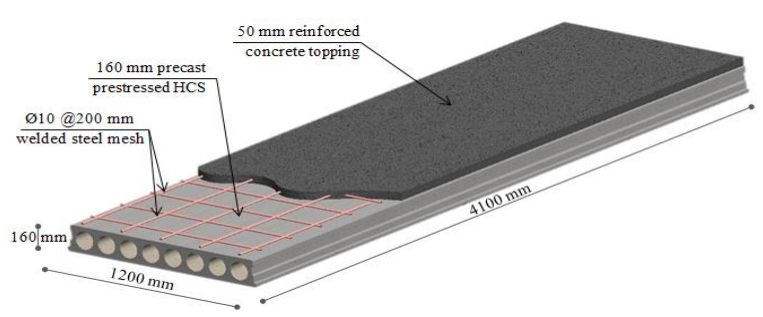

Fig. 2: PPHC slabs with ordinary RC toppings without steel anchors - Group 2 

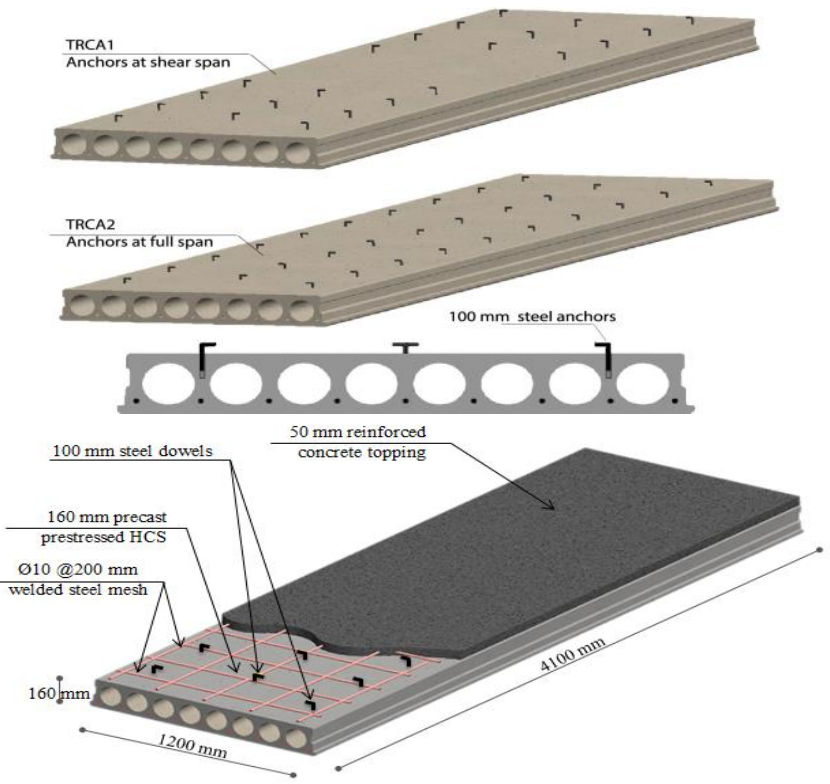

Fig. 3 PPHC slabs with ordinary RC toppings with steel anchors - Groun 3

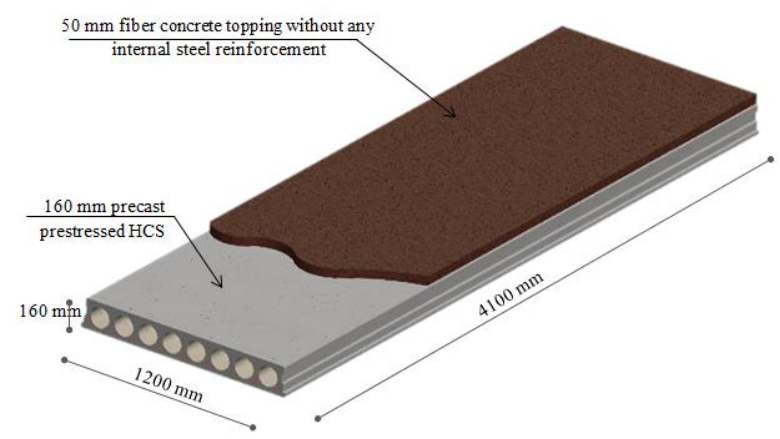

Fig. 4: Details of PPHC slab with fibrous concrete toppings - Group 4

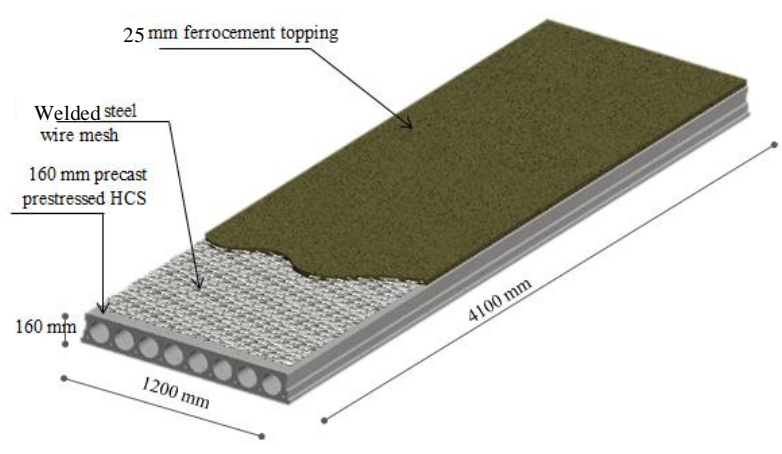

Fig. 5: Details of PPHC slab with ferrocement toppings - Group 5

unit weight of concrete used is $24 \mathrm{kN} / \mathrm{m}^{3}$. Concrete used for toppings in Groups 2 and 3 are normal strength concrete with cube compressive strength of 25 $\mathrm{MPa}$.

\section{b. Fibrous concrete}

Two types of fibrous concrete are used as toppings, glass fiber and steel fiber concrete. $6 \mathrm{~mm}$ length measuring 13 microns in diameter monofilament glass fibers chopped from type $\mathrm{E}$ of glass are used to produce glass fiber concrete. The fibers are extremely fine, single filaments; fibers are coated with Silane based to improve initial dispersion and bond. $0.26 \%$ of cement weight was added to the mixture according to manufacturer bulletin ${ }^{[15]}$.

Steel fiber concrete was prepared using high tensile undulated steel fibers made of cold drawn wire. Corrugated steel fibers are $55 \mathrm{~mm}$ in length and 0.8 $\mathrm{mm}$ diameter with aspect ratio $1 / \mathrm{d}: 68.75$, fibers wire tensile strength is $1000 \mathrm{~N} / \mathrm{mm}^{2} .5 .7 \%$ of cement weight was added to the mixture according to manufacturer data sheet ${ }^{[16]}$.

\section{c. Ferrocement}

The ferrocement laminates are reinforced using steel meshes locally produced and available in the market on commercial scale. Mesh grid size is $15 \times 15 \mathrm{~mm}$ with $1 \mathrm{~mm}$ wire diameter. For concrete mortar, water/cement ratio used was 0.4 , and the selected sand/cement ratio was 2.0.

\subsubsection{Reinforcement materials}

Nine uncoated bright steel 7-wire P.C. strand $(9.3 \mathrm{~mm}$ nominal diameter with nominal area of $52 \mathrm{~mm}^{2}$ ) lowrelaxation strands were used. Average ultimate tensile strength was found to be $1,860 \mathrm{MPa}$ and modulus of elasticity was $200 \mathrm{GPa}$ respectively.

Physical and mechanical properties for used materials are listed in Tables 2 and 3.

Table 2: Topping materials properties

\begin{tabular}{|c|c|c|}
\hline Topping & Thickness & Compressive \\
\hline Ordinary & 50 & 25 \\
\hline Steel fiber & 50 & 32 \\
\hline Glass fiber & 50 & 36 \\
\hline Ferrocement & 25 & 25 \\
\hline
\end{tabular}

Table 3: Reinforcement materials properties

\begin{tabular}{|c|c|c|c|c|}
\hline $\begin{array}{c}\text { Reinforce } \\
\text { ment }\end{array}$ & $\begin{array}{c}\text { Yield } \\
\text { stress }\end{array}$ & $\begin{array}{c}\text { Ultima } \\
\text { te }\end{array}$ & $\begin{array}{c}\text { Diamet } \\
\text { er }\end{array}$ & $\begin{array}{c}\text { Mesh } \\
\text { spaci }\end{array}$ \\
\hline Prestressin & - & 1860 & 9.3 & - \\
\hline $10 \mathrm{~mm}$ & 360 & 520 & 10 & 200 \\
\hline Steel & 240 & 350 & 8 & - \\
\hline $\begin{array}{c}\text { Welded } \\
\text { wire mesh }\end{array}$ & $\begin{array}{c}\text { Proofing } \\
\text { stress }\end{array}$ & 700 & 1 & 15 \\
\hline
\end{tabular}




\subsection{Test setup}

Test specimens are loaded statically using two line loads. The load was applied on the slab using two similar-sized steel I-sections in the loading frame, at approximately third points. The hollow-core slabs are supported on two stiff steel I-sections. The distance from the center line of the support to the end of PPHC slab is $5 \mathrm{~cm}$ giving a clear span of $4.0 \mathrm{~m}$. A $500 \mathrm{kN}$ hydraulic jack was used to apply the load gradually with a constant increment. The complete detailed setup for testing of the hollow-core slabs is shown in Fig. 6.

\subsection{Measuring Devices}

The deflections at the center of the slabs and the center line of applied load were measured by three mechanical and electrical dial gauges $(25$ and $50 \mathrm{~mm})$ attached to the bottom of the slabs. Demec points were attached to the concrete surface to measure concrete strain. The slabs were loaded gradually $(5 \mathrm{kN}$ per increment) until failure .The cracking load, failure progression and the cracks developed in the slab were recorded. The testing equipment and the test setup are shown in Figs. 7 and 8.

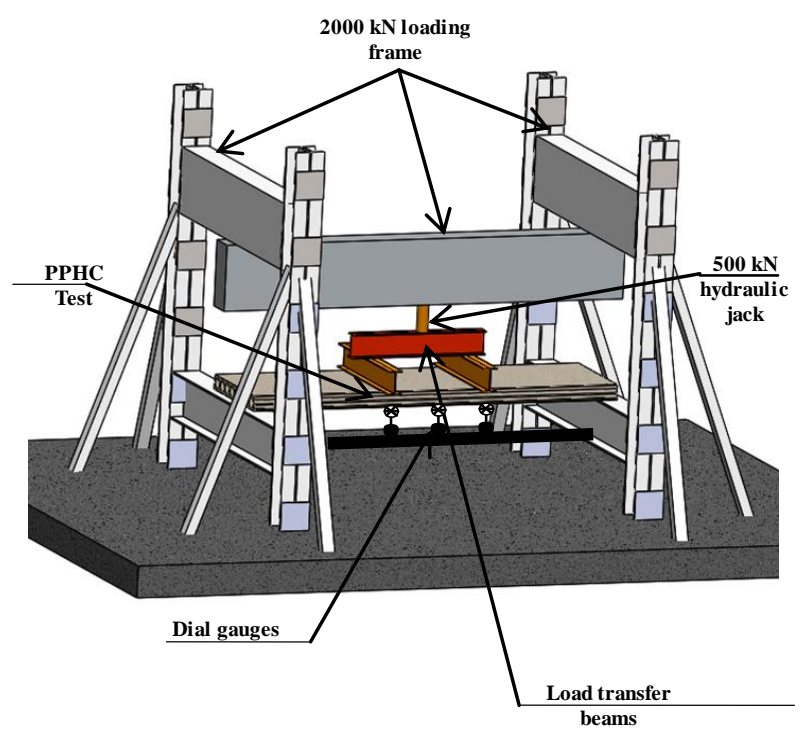

Fig.6: 3D illustration for loading setup

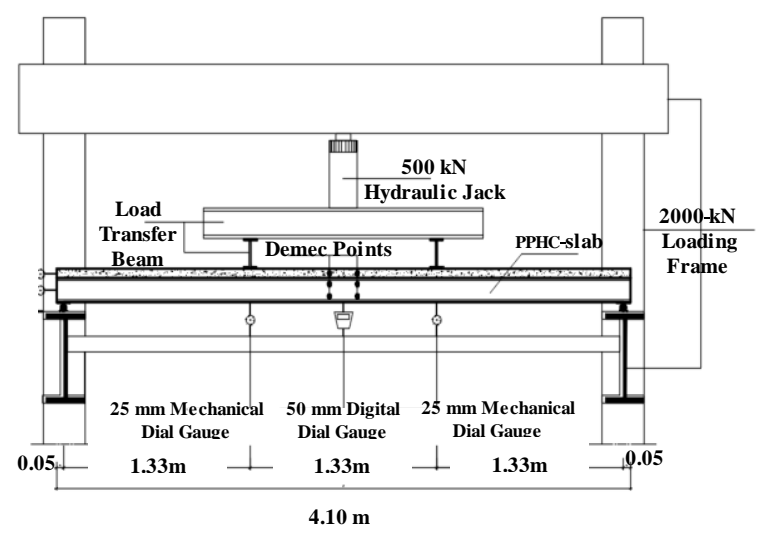

Fig.7: Schematic of test setup and instrumentations

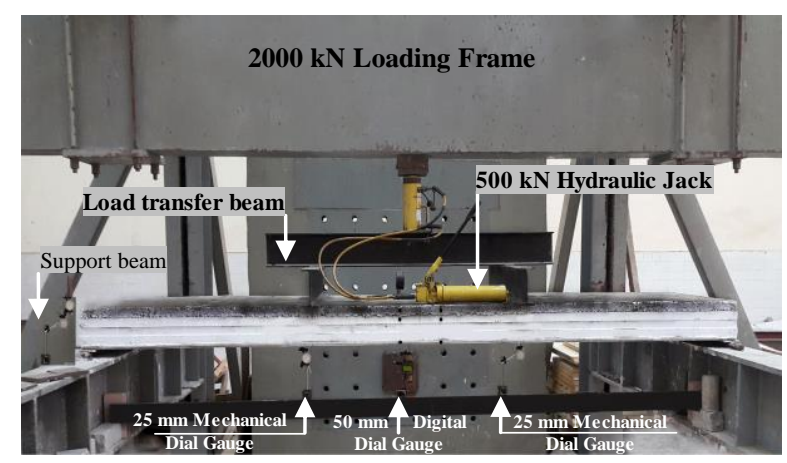

Fig.8: Test setup and instrumentation at lab

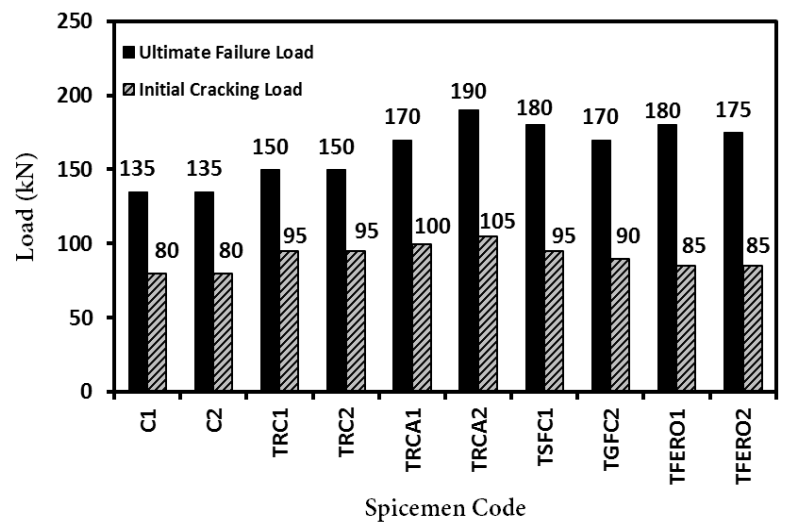

Fig. 9: Comparison of cracking and failure loads for all tested PPHC specimens

\subsection{RESULTS AND DISCUSSION}

\subsubsection{Cracking and failure loads}

Figure 9 shows comparison between cracking and failure loads for the tested specimens. Cracking load was recorded upon emersion of first crack in slab soffit. Whereas failure load was determined as slab resistance to load decreased significantly. Cracks propagation in all tested slabs followed the similar conventional flexural patterns in simply supported slabs. Initiation of flexural cracks on PPHC specimens was observed to occur at middle third of the span directly below the applied load. As the loading increased, new cracks were formed on either side of the loading point. Control specimens $\mathrm{C} 1$ and $\mathrm{C} 2$ were first cracked on $80 \mathrm{kN}$ with failure loads of $135 \mathrm{kN}$ for both specimens.

Applying traditional concrete topping in Group 2 leads to a direct enhancement in load carrying capacity and consequently improvement in flexural resistance of the slab. Cracking load resistance increased to reach 95 $\mathrm{kN}$ with a gain of about $19 \%$. The increase in failure load for the same group was about $11 \%$ as the failure load reached $150 \mathrm{kN}$. 
In the third group which includes traditional concrete topping in addition to steel anchors, the improvement in cracking capacities were about $25 \%$, and $31 \%$ for specimens TRCA1 and TRCA2 respectively as the cracking load touches $100 \mathrm{kN}$, and $105 \mathrm{kN}$. Whilst raise in failure loads were about $26 \%$, and $41 \%$ for loads $170 \mathrm{kN}$ and $190 \mathrm{kN}$ respectively.

In the fourth group, in which two types of fibrous concrete topping were used, the cracking loads were $95 \mathrm{kN}$ and $90 \mathrm{kN}$ for TSFC1 and TGFC2 with a total gain of about $19 \%$ and $13 \%$ respectively. On the other hand, the failure loads for this group were $180 \mathrm{kN}$ and $170 \mathrm{kN}$ with about $33 \%$ and $26 \%$ enhancement in ultimate capacities for TSFC1 and TGFC2 respectively.

In The last group which includes hollow core slabs with ferrocement topping, the cracking load was $85 \mathrm{kN}$ for both TFERO1 and TFERO2 with a slight gain of about $6 \%$, on the contrary the failure loads reached $175 \mathrm{kN}$ and $180 \mathrm{kN}$ with about $30 \%$ and $33 \%$ enhancement in ultimate capacity. Figure 10 also shows cracking and failure moments for the all tested specimens.

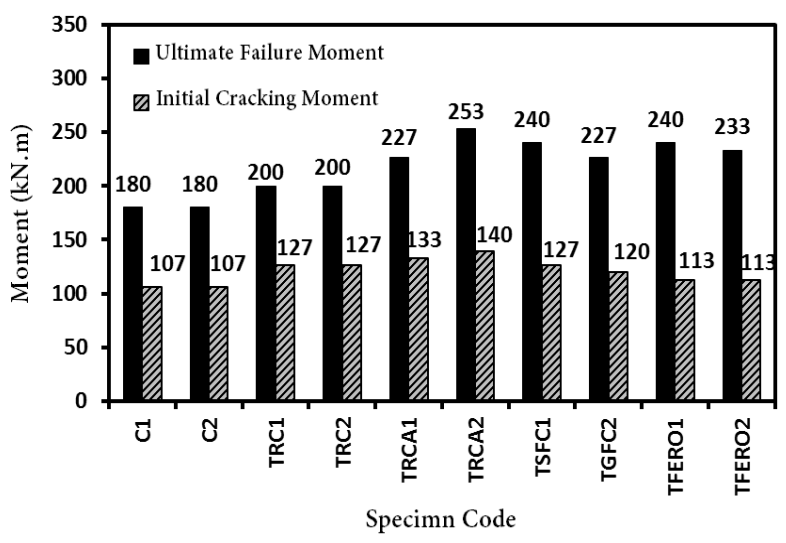

Fig. 10: Comparison of cracking and failure moment for all tested PPHC specimens

\subsubsection{Failure modes and crack patterns}

The hollow core slabs may fail by many modes, flexural failure modes may be represented by concrete cracking at top due to prestress transfer, concrete cracking at bottom, and rupture of prestressing strands, crushing of concrete at top or excessive deflection under loads. While shear failure modes may be seen by bond slip failure of strand, flexural shear failure, or web shear failure ${ }^{[2,17,18]}$, see Fig. 11.

In this study, flexural and shear modes were observed in the tested specimens as concrete cracking at bottom, flexural shear failure, and web shear failure. Crack patterns and some failure modes are presented in Figs. 12 - 19.

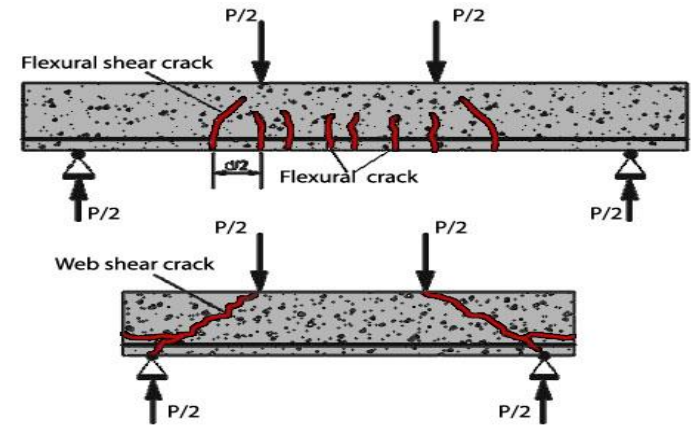

Fig.11: Flexural, flexure-shear, and webshear cracks in HCS ${ }^{[17]}$

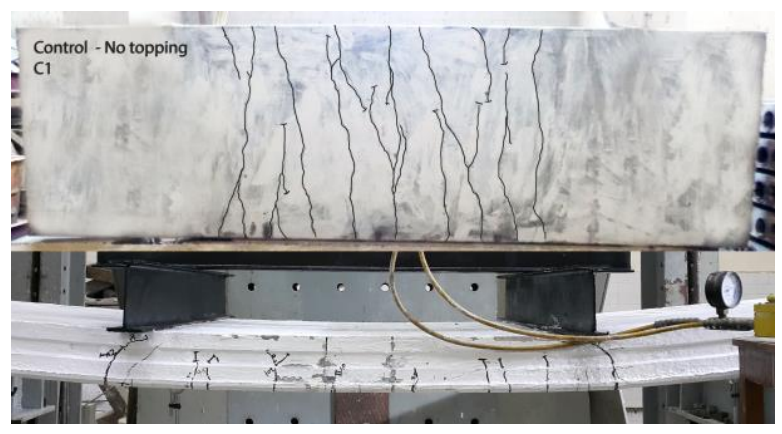

Fig.12: Crack patterns, crack distribution and failure mode for control specimen $\mathrm{C} 1$

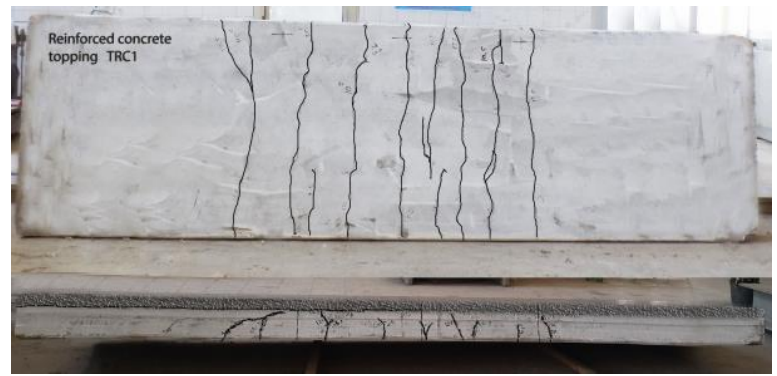

Fig.13: Crack patterns, crack distribution and failure mode for specimen TRC1

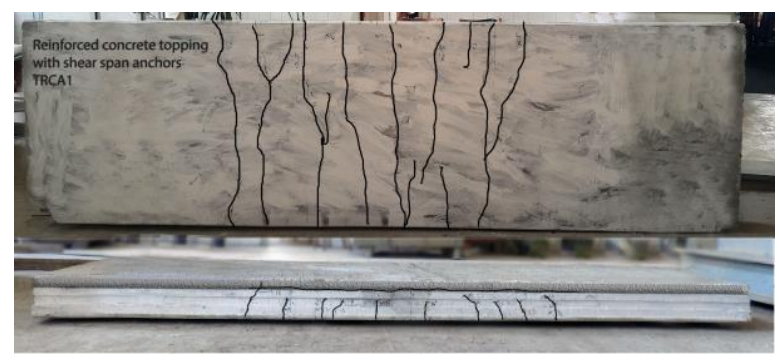

Fig.14: Crack patterns, crack distribution and failure mode for specimen TRCA1

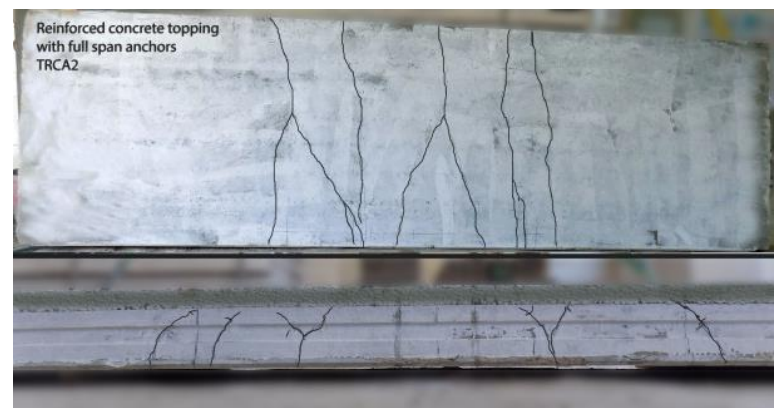

Fig.15: Crack patterns, crack distribution and failure mode for specimen TRCA2 


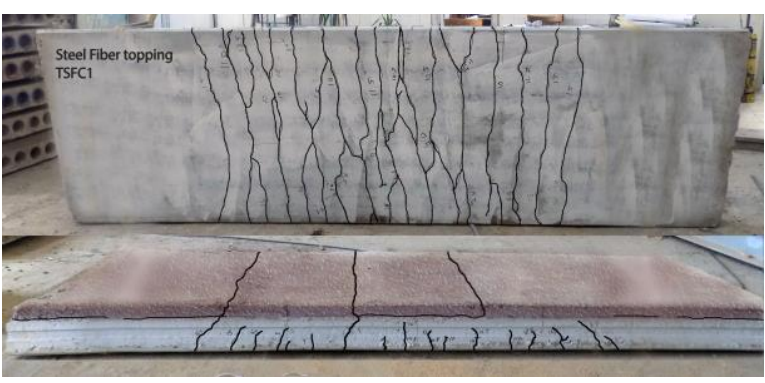

Fig.16: Crack patterns, crack distribution and failure mode for specimen TSFC1

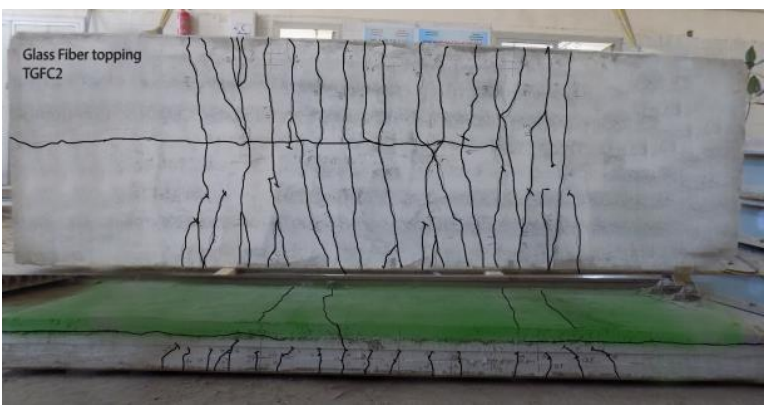

Fig.17: Crack patterns, crack distribution and failure mode for specimen TGFC2

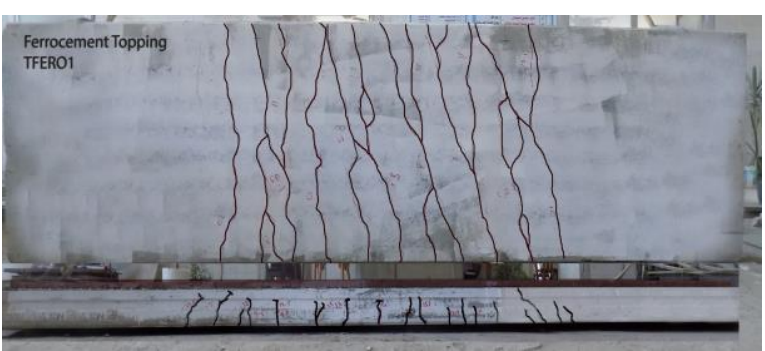

Fig.18: Crack patterns, crack distribution and failure mode for specimen TFERO1

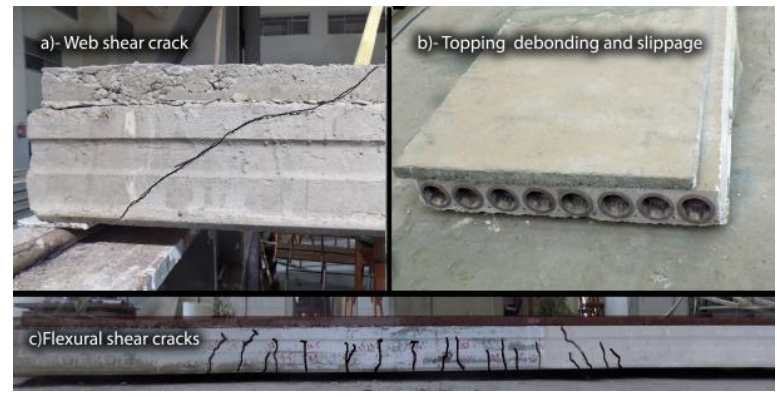

Fig. 19: Some cracks modes and slippage of concrete toppings in tested specimens

\subsubsection{Moment- deflection behavior}

Observation of initial flexural cracks on PPHC slabs was occurred at slabs mid span directly below the applied loads. When the cracks were visually detected for the first time, they usually extended from bottom into almost half of the depth of PPHC slab. As the loading continued, new cracks appeared on either side of the loading point. Cracking was reflected through a change in slope of the load-deflection curve, after concrete cracking; strands started resisting the applied load until specimen failure. A typical under-reinforced behavior for bending stresses was clearly noticed on moment deflection curves for tested specimens. The moments versus mid-span deflections responses of the PPHC slabs are listed hereunder in the following subsections.

\section{a. Effect of using traditional reinforced concrete toppings without steel anchors}

Figure 20 shows moment deflection curves for the third group; in which traditional reinforced concrete toppings were used, results were compared to the control specimens. In pre-cracking and post cracking stage deflection behavior shows lower deformability and higher stiffness. In pre-cracking stage, the highest deflection was $8.21 \mathrm{~mm}$ for $\mathrm{C} 2$ at a cracking moment of about $107 \mathrm{kN} . \mathrm{m}$, Specimens TRC1 and TRC2 show deflections of 8.41 and $9.24 \mathrm{mms}$ respectively at cracking moments of about $127 \mathrm{kN} . \mathrm{m}$ for both specimens. In the post cracking stage, the highest deflection was $57.78 \mathrm{~mm}$ for $\mathrm{C} 2$ at a failure moment of 180 kN.m, Specimens TRC1 and TRC2 show deflections of 72.48 and $72.4 \mathrm{mms}$ respectively at a failure moment of $200 \mathrm{kN} . \mathrm{m}$ for both units.

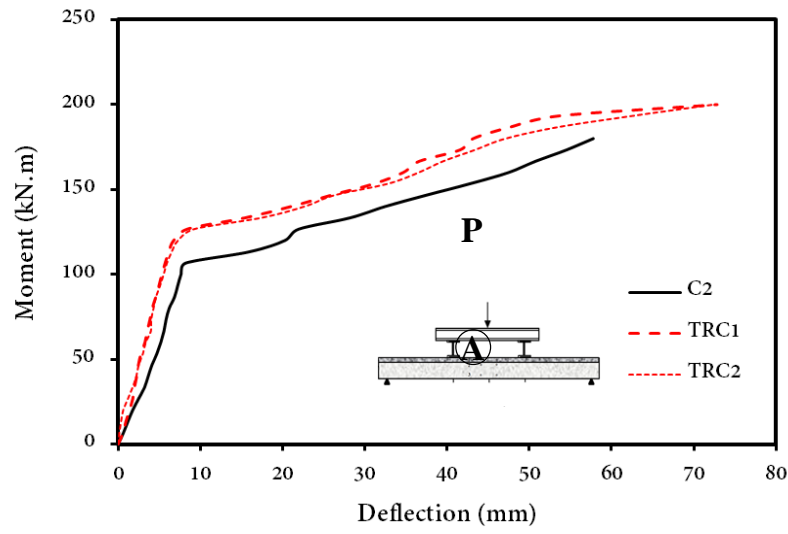

Fig. 20: Moment-deflection curves at mid-span for specimens TRC1, TRC2 in Group 2

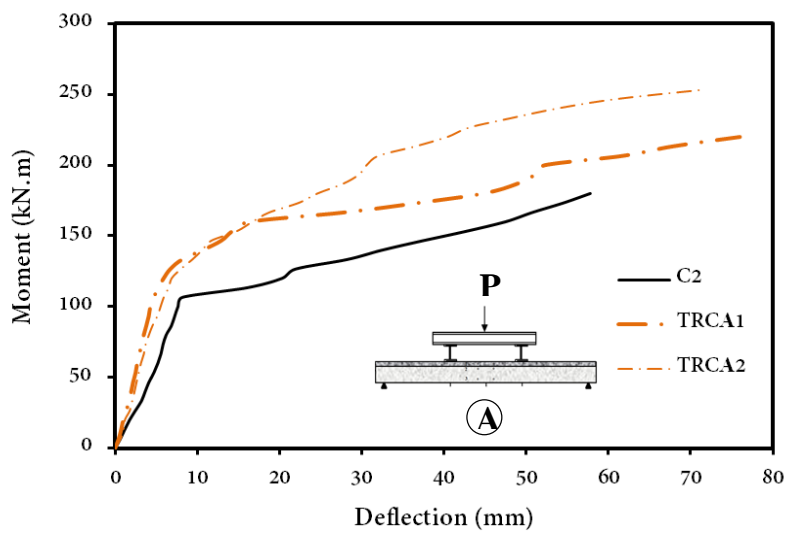

Fig. 21 : Moment-deflection curves at mid-span for specimens TRCA1, TRCA2 in Group 3 


\section{b. Effect of using traditional reinforced concrete toppings with steel anchors}

Figure 21 shows moment deflection curves for the third group; in which traditional reinforced concrete toppings were used in addition to steel anchors located in the shear span for specimen TRCA1 and in full span in specimen TRCA2. These results were compared to the control specimens. In pre-cracking and post cracking stage, deflection behavior shows excellent performance as there was full composite action till failure in TRCA2, while specimen TRCA1 shows composite action only in pre-cracking stage. Both units reflected lower deformability and higher stiffness. In pre-cracking stage the highest deflection was $8.21 \mathrm{~mm}$ for $\mathrm{C} 2$ at a cracking moment of about 107 kN.m, Specimens TRCA1 and TRCA2 showed deflections of 6.72 and $10.58 \mathrm{mms}$ at cracking moments of about 127 kN.m and 140 kN.m respectively. In the post cracking stage, the highest deflection was 57.78 $\mathrm{mm}$ for $\mathrm{C} 2$ at a failure moment of $180 \mathrm{kN} . \mathrm{m}$, Specimens TRCA1 and TRCA2 show deflections of 85.17 and $71.5 \mathrm{mms}$ at a failure moments of about 227 $\mathrm{kN} . \mathrm{m}$ and $253 \mathrm{kN} . \mathrm{m}$ respectively.

\section{c. Effect of using fibrous concrete toppings}

Moment-deflection curves for the fourth group are shown in Fig. 22. Two types of fibrous concrete toppings were used in this group. The results were compared with the control specimen. In pre-cracking and post cracking stages, deflection behavior showed lower deformability and higher stiffness. In precracking stage, the highest deflection was $8.21 \mathrm{~mm}$ for $\mathrm{C} 2$ at a cracking moment of about $107 \mathrm{kN} . \mathrm{m}$, specimens TGFC2 and TSFC1 showed deflections of 9.5 and $9.29 \mathrm{mms}$ at cracking moments of about 120 kN.m and 127 kN.m respectively. In the post cracking stage, the highest deflection was $57.78 \mathrm{~mm}$ for $\mathrm{C} 2$ at a failure moment of $180 \mathrm{kN} . \mathrm{m}$, specimens TGFC2 and TSFC1 showed deflections of 95.7 and $127.5 \mathrm{mms}$ at a failure moments of about $227 \mathrm{kN} . \mathrm{m}$ and $253 \mathrm{kN} . \mathrm{m}$ respectively.

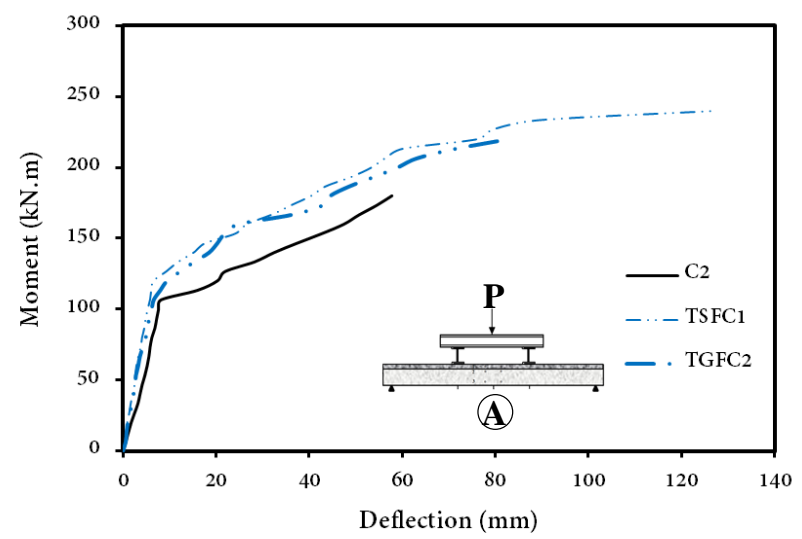

Fig. 22: Moment-deflection curves at mid-span for specimens TSFC1, TGFC2 in Group 4

\section{d. Effect of using ferrocement toppings}

Ferrocement concrete toppings were used in Group 5 as a thin topping to enhance flexural capacity of PPHC slabs; Fig. 23 shows moment deflection curves for PPHC slabs with ferrocement topping. The results of this group were compared with the control specimen. Both specimens reflected lower deformability and higher stiffness. In pre-cracking stage, the highest deflection was $8.21 \mathrm{~mm}$ for $\mathrm{C} 2$ at a cracking moment of about 107 kN.m, Specimens TFERO1 and TFERO2 showed deflections of 13.55 and $13.88 \mathrm{mms}$ at cracking moments of about $113 \mathrm{kN}$.m for both.

In the post cracking stage, the highest deflection was $57.78 \mathrm{~mm}$ for $\mathrm{C} 2$ at a failure moment of $180 \mathrm{kN} . \mathrm{m}$, specimens TFERO1 and TFERO2 showed deflections of 99.32 and $89.92 \mathrm{mms}$ at a failure moments of about 240 kN.m and 233 kN.m respectively.

Figure-24 shows comparison between moment deflection curves for second and third groups compared to control specimens. Concrete topping with steel anchors in the third group shows the best performance in stiffness, deformability, cracking resistance and failure load as shown below.

Comparison between moment deflection curves for fourth and fifth groups is shown in Fig. 25 which shows better performance in deformability and higher cracking moment resistance for fibrous concrete. The two groups are equal in failure loads. Finally, moment deflection curves for all tested specimens are shown in Fig. 26.

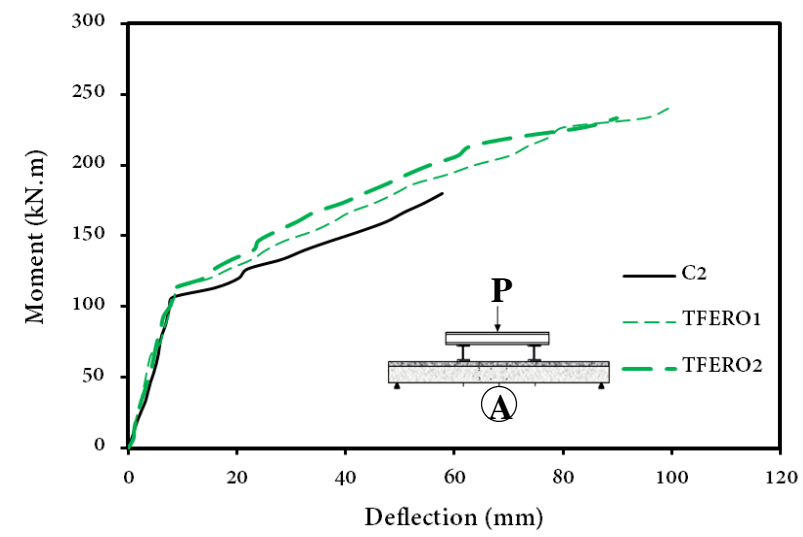

Fig. 23: Moment-deflection curves at mid-span for specimens TFERO1, TFERO2 in 


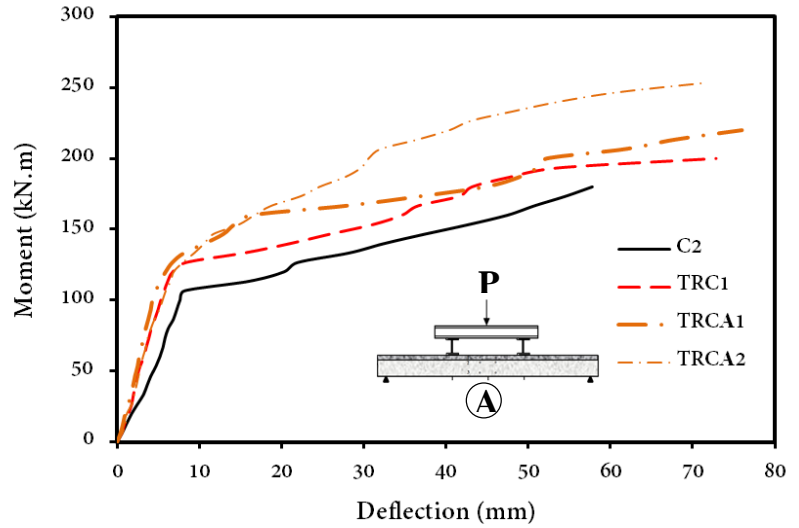

Fig. 24: Comparison between moment-deflection curves at mid span for Groups 2 and 3

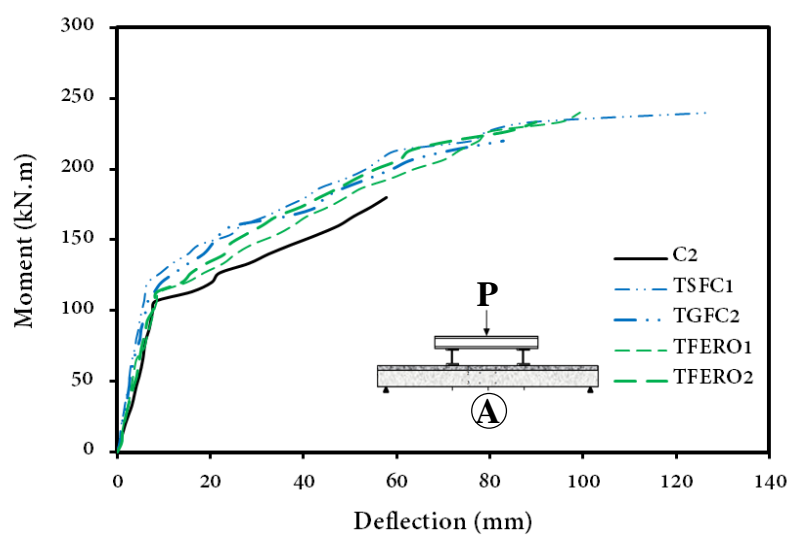

Fig. 25: Comparison between moment-deflection curves at mid span for Groups 4 and 5

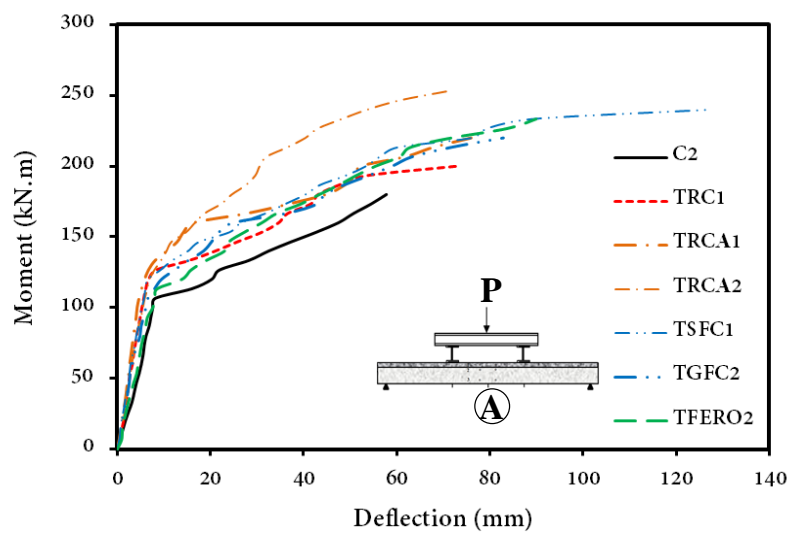

Fig. 26: Comparison between moment-deflection curves at mid span for all groups

\section{CONCLuSions}

Full scale tests for ten PPHC slabs were carried out to investigate the extent to which a concrete topping placed over the top surface improves the structural behavior of the slabs. The following conclusions can be drawn:

1. Adding different types concrete topping to the PPHC slabs enhances flexural behavior directly under static line loading, as the cracking moment resistance was increased by about $6 \%$ to $31 \%$ and failure moment was increased by about $11 \%$ to $41 \%$ by using concrete toppings.

2. Using steel anchors to connect the concrete toppings to PPHC slabs has great effects on slab performance, it leads to less deformability and higher stiffness as it prevents slippage between PPHC slab and concrete topping especially for case of full span anchors. Deflection at failure for specimens without using anchors was about $72 \mathrm{~mm}$ at failure load of $150 \mathrm{kN}$, while deflection for the same load in case of using full span anchors was about $31 \mathrm{~mm}$. Full composite action was occurred by using steel anchors in full span rather than shear span. Cracking moment and ultimate failure moment capacities were enhanced by about $10 \%$ and $27 \%$ for full span anchors compared with specimens using RC toppings without anchors.

3. Fibrous concrete topping without using any internal conventional reinforcement achieved higher cracking resistance, ultimate resistance with less deformability and higher stiffness. Cracking moment and ultimate failure moment capacities were enhanced by about $12 \%$ and $26 \%$ for glass fiber topping and $19 \%$ and $33 \%$ for steel fiber topping respectively compared with control specimens.

4. Reducing total slab thickness and load by using thin layer of ferrocement topping was also an effective technique, as it enhances the ultimate moment capacity considerably. Cracking moment capacity enhanced by about $6 \%$ and ultimate moment capacity improved by about $33 \%$. 


\section{ACKNOWLEDGMENTS}

The authors wish to express their special thanks to Modern Concrete for their technical and financial support.

\section{References}

[1] L.V. Prakashan, J. George, J. B. Edayadiyil, J. M. George, "Experimental Study on the Flexural Behavior of Hollow Core Concrete Slabs", Applied Mechanics and Materials, Vol. 857, pp. 107-112, 2017.

[2] M. Rahman and M. Baluch, "Flexural and Shear Strength of Prestressed Precast Hollow-Core Slabs," Arabian Journal for Science and Engineering, vol.37-2, pp. 443-455, 2012.

[3] E. Cuenca and P. Serna, "Failure Modes and Shear Design of Prestressed Hollow Core Slabs Made of Fiber-Reinforced Concrete," Engineering Composites. Part B, vol.45, pp.952-964, 2013.

[4] D. R. Buettner and Roger J. Becker, "Manual for the Design of Hollow Core Slabs", Second Edition , Precast / Prestressed Concrete Institute ,175 West Jackson Boulevard Chicago,Illinois, 1998.

[5] PCI Industry Handbook Committee, "PCI Design Handbook- Precast and Prestressed Concrete- 6th Edition", 2004.

[6] A. Adawi, "Shear and Peel Stresses at the Interface between Hollowcore Slabs and the Topping Concrete", PhD thesis, University of Western Ontario London, Ontario, Canada, 2015.

[7] R. M. Mones and S. F. Breña, "Hollow-Core Slabs with Cast-in-Place Concrete Toppings: A study of Interfacial Shear Strength," PCI Journal, vol. 58, no. 3, pp. 124-141, 2013.

[8] F. Elgabbas, A. A. El-Ghandour, A. A. Abdelrahman, and A. S. El-Dieb, "Different CFRP Strengthening Techniques for Prestressed Hollow Core Concrete Slabs: Experimental Study and Analytical Investigation" , Composite Structures, vol. 92, no. 2, pp. 401-411, 2010.

[9] Kh, Heiza, A. Nabil, N. Meleka, and M.Tayel "State-of-the Art Review: Strengthening of Reinforced Concrete Structures - Different Strengthening Techniques," in Sixth International Conference on Nano-Technology in Construction, pp. 1-24, Egypt, March 2014.

[10] F. Mansour and S. Bakar, "Flexural Performance of A Precast Concrete Slab with Steel Fiber Concrete Topping," Construction and Building Materials, vol. 75, pp. 112-120, 2015.

[11] E. Baran, "Effects of Cast-In-Place Concrete
Topping on Flexural Response of Precast Concrete Hollow-Core Slabs," Engineering Structures, vol.98, pp.109-117, 2015.

[12] R. M. Mones, "Interfacial Strength Between Prestressed Hollow Core Slabs and Cast-In-Place Concrete Topping," Master thesis, University Of Massachusetts Amherst, February, 2012.

[13] S. I. Haruna, "Flexural Behavior of Precast Prestressed Concrete Hollow Core Slabs with Cast-in-Place Concrete Topping,"Master thesis , Atılım University, May 2014.

[14] A. Adawi, Maged A. Youssef, Mohamed E. Meshaly, "Experimental Investigation of the Composite Action between Hollowcore Slabs with Machine Cast Finish And Concrete Topping," Engineering Structures, Vol. 91, pp. 1-15, 2015.

[15] Twin Tec Industrial flooring, "Steel Fibres AFT 0.8/55 High Strength Undulated Steel Fibres", Technical Data Sheet, pp. 1-2, Nov. 2016.

[16] SIKA Egypt, "SikaFiber (G) ${ }^{\circledR}$ Monofilament Glass Fibers", Product Data Sheet, Edition 2, 2015

[17] U. Girhammar, "Design Principles for Simply Supported Prestressed Hollow Core Slabs," Structural Engineering Review., Vol. 4, No.4, pp. 301-306, 1992.

[18] F. Steven, K. Mahmoud, and E. ElSalakawy"Behavior of Prestressed Hollow-Core Slabs Strengthened in Flexure with Near-Surface Mounted Carbon Fiber-Reinforced Polymer Reinforcement." Journal of Composites for Construction 20, no. 6 (2016). 